\title{
Reflection of Indonesian Economic Development Model Approach Through the Economic and Social Dynamics Ibnu Khaldun
}

Muhammad Sri Wahyudi Suliswanto, Setyo Wahyu Sulistyono, Zainal Arifin, and Muhammad Faisal Abdullah

\section{Abstract}

The development concept in Islam to refer to the socio-economic dynamics that previously triggered by cendikawan Islam Ibnu Khaldun and later developed by Umer Chapra. Therefore, the objective of this research that reflects the economic development in Indonesia by using a model of socio-economic dynamics of Ibnu Khaldun. The method is qualitative descriptive research in the form of linkages between concepts empirically elaboration on the meanings contained within a historically through

Corresponding Author: Muhammad Sri Wahyudi Suliswanto

al.ayudie@gmail.com

Received: 10 February 2019 Accepted: 14 March 2019 Published: 28 March 2019

Publishing services provided by Knowledge E

(c) Muhammad Sri Wahyudi Suliswanto et al. This article is distributed under the terms of the Creative Commons

Attribution License, which permits unrestricted use and redistribution provided that the original author and source are credited.

Selection and Peer-review under the responsibility of the ICIEBP Conference Committee.

\section{S OPEN ACCESS} the power of literature. The data source is secondary to the research literature as well phenomenology reflected the situation in Indonesia.

The results obtained in this study related to develop Indonesia lost direction in determining development by focusing objections on political interests run to replace the role of the state as the subject of development that each era of leadership to change the focus of economic development, where each era had a blast effect on the economic life, condition is compounded when all elements of executive e and legislative government nor the bureaucracy to act emphasizes moral hazard such as corruption, it favors only certain groups and communities to act as a tool of legitimacy, which we know in every era has thought leadership without considering sustainability policy

Keywords: Economic Development; Ibnu Khaldun; Islamic Economics

\section{Introduction}

Ibnu Khaldun through socio-economic dynamics models, contributed in the treasures of Islamic Economics. The subsequent cycle was Developed by Chapra, complete with a causal known as the cycle of progress and setbacks of a dynasty, nation or civilization, or so-called Cycle Chapra (Sholihin, 2013).

The development of civilization itself has the journey begins process of primitive civilization, there also are urban or modern, in the human civilization in the form of the personal context of individual and social personal interaction, civilization itself is divided 
into: First). Human civilization in general and the manifold earth. Second), primitive civilizations, tribes and wild nation. Third, the empire, the Caliphate, the empire, and the levels of the empire. Fourth), and the urban civilization. Fifth), profession, business, livelihood, and other kinds. Sixth), science and ways to obtain it. Pursuant to the terms of each civilization will find these phases in a person's life, in this phase will bring on a condition that affects a person's thought patterns and needs (Bin Khaldun, M., \& Rahman, 2011).

Socio-economic model of Ibnu Khaldun is formulated in a cycle by the Chapra, filled by components which consists of five components, namely the Government / state $(G)$ / (Khilafah), Shariah (S), Ummat / public (N), Wealth / welfare (W), construction and law (j $\& \mathrm{~g})$. These components form the core of the formation of an Islamic society.

Excavation Ibnu Khaldun to sociology and history mean in a subjective truth based on experience, received by the logical sense that proved empirically, which contrasted with the previous intellectual, social phenomena subsequently used as a form of realizing a good society, subject to the rules (Hashim, 2012).

According to Chapra in (Rikmat Ismatullah, 2009) The fifth component is moving in two cycles, the cycle of progress and setbacks cycle. Cycle progress moving clockwise, namely the government, the Shariah, Ummah (community), property, construction law and then returned to the government. Cycle setback move opposite of the government, construction and legal, property, community, Shariah and back to the government.

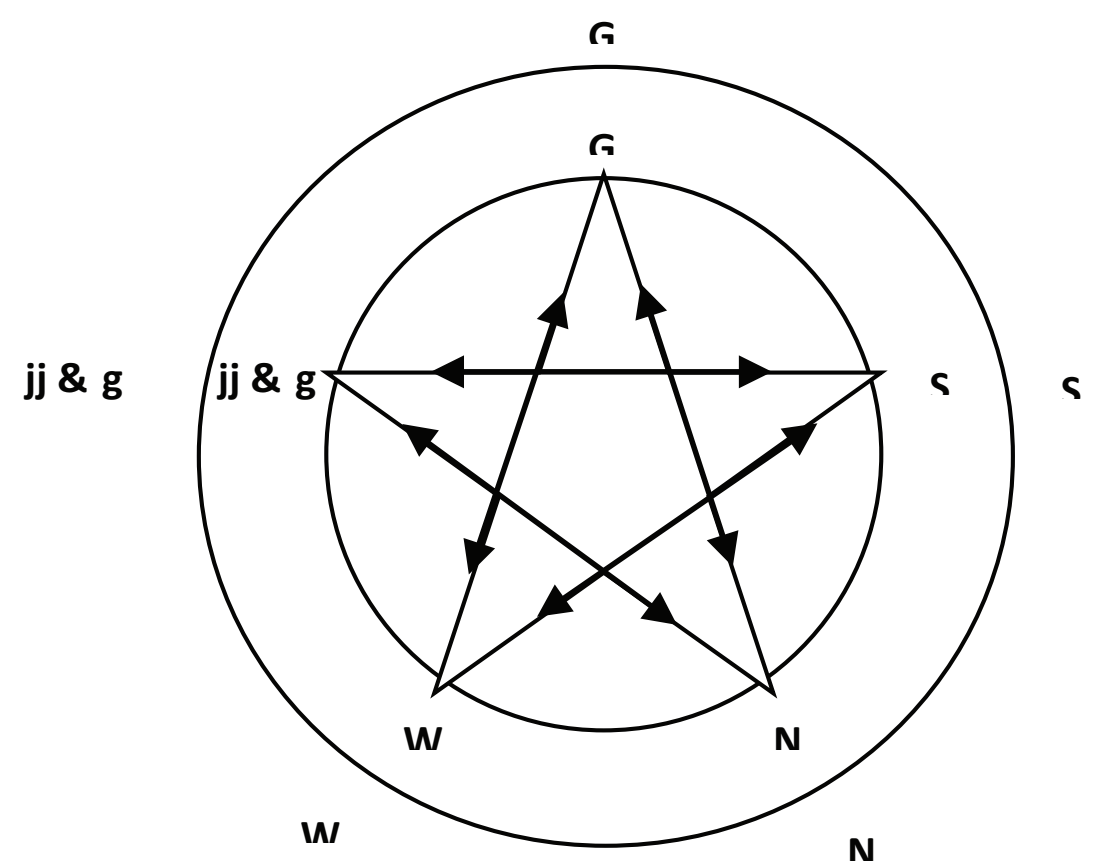

Figure 1: DYNAMIC MODEL socio-economic Ibnu Khaldun (Cycle Progress and Setbacks a Country / Civilization). 
Starting from the Shari'ah (S), Shariah refers to the values and institutions or rules of conduct that make people $(\mathrm{N})$ is willing to fulfill their obligations towards others and preventing socially deviant behavior. Rules of conduct can be both formal and informal either written or unwritten for main guide behavior in an Islamic society called the Shari'ah (S). Shariah will not be able to play a significant role unless the Shariah is implemented correctly and impartially in its implementation.

Syari'ah help people $(\mathrm{N})$ instill kindness qualities like obedience, honesty, integrity, humility, and a sense of community that can contribute to the development process, justice, mutual understanding, cooperation, peace and harmony as well as controlling behavior that can endanger the public. Syari'ah can use moderate influence on the use of resources and thus the shariah can contribute to balance resources. Without all of these qualities in the community $(\mathrm{N})$, will be injustice, imbalance, discontent and chaos that will ultimately lead to a deterioration and disintegration of society. Community $(\mathrm{N})$ which has been filled by the values taken by the Shari'ah (S) are social creatures who prefer to live together. This is because their individual capacity. society is expected -after spiked by Syariah- will implement the concept of brotherhood in Islam that makes people $(\mathrm{N})$ in collaboration with others for the same purpose, establish social harmony and pose a decisive force for the development and enforcement of a civilization.

A society filled with the principle of common purpose homo Islamicus which will act both individually and collectively in a society filled within the framework of the norms of ethical-political-specific law, for example, justice, virtue, similarities in the behavior, assuming it will result in economic outcome that is fair, equitable and optimal in reviving the Islamic economic system in the economic order as well as living (Mahyudi, 2015)

Wealth (W) or the welfare of the community are equally important factor after the people who form the social harmony and generate power. It must be maintained, and the weakness or strength of the community depends on the wealth / welfare (W) and (g) development. Therefore welfare (W) developed by Ibnu Khaldun in which wealth / welfare (W) is dependent on economic activity, the number and division of labor, the extent of the market, benefits and facilities provided by the state as well as equipment which in turn depends on savings or "the resulting surplus after meeting the needs of society".

Two of the most important hook in the cycle is the development of $(\mathrm{g})$ and justice (j). Development is considered important because the normal tendency in society to change, the tendency can be increased and decreased. In this discussion, the development is not solely referring to the economic growth. The development also refers to the full human development so that each of these variables $(G, S, N$ and $W$ ) 
enrich each other. In this way all the proficiency level variables contribute to the welfare and advancement of civilization. However the development also would not have been possible without the presence of justice (j). Justice is meant here is also not in the narrow sense of economic justice but rather on understanding the broader justice in every aspect of human life. Justice in this broad context that can not be fully realized without creating a society $(\mathrm{N})$ which has been described in the affairs of society. Justice can also be created to guarantee the safety of lives, property and honor of every person, the fulfillment of social, economic and political, the right to freely determine what action is desired by a person and the prevention of crime and injustice in any form. Justice (j) would ensure the public welfare through the fulfillment of mutual obligations and the equitable distribution of development outcomes (W \& G). property rights and respect for each person, the fulfillment of social, economic and political, the right to freely determine what action is desired by a person and the prevention of crime and injustice in any form. Justice (j) would ensure the public welfare through the fulfillment of mutual obligations and the equitable distribution of development outcomes (W \& G). property rights and respect for each person, the fulfillment of social, economic and political, the right to freely determine what action is desired by a person and the prevention of crime and injustice in any form. Justice (j) would ensure the public welfare through the fulfillment of mutual obligations and the equitable distribution of development outcomes (W \& $G$ ).

Based on Ibnu Khaldun's thought humans play a role in the rise and fall of civilization is closely dependent on welfare or misery. This, in turn, depends not only on economic variables but also on the role of moral factors are closely related, institutional, psychological, political, social and demographic through causal processes over a long period of history. The emphasis on the human being is in accordance with the teachings of the Koran which states that: "Allah does not change the condition of a people until they change their own destiny" and that "Corruption has appeared everywhere because of what people have been doing various damage it gave emphasis on role the man himself in the rise and fall of them (Chapra, 2007).

Loss of justice (j) tend to cause dissatisfaction among the people $(N)$. However, there would be no moral rules are effective if people do not understand the benefits of such moral rules. Furthermore, the functions of the state $(G)$ or political power. Political power $(G)$ which can effectively ensure that all to meet the needs of society at large. Political power $(G)$ have the same relationship as well as the civilization in the problems that it faces. It is impossible to form a political power in the absence of civilization and no civilization without any political power. Ibnu Khaldun classifies power into three types. The first type) are natural or normal power that each person is allowed to satisfy 
their personal interests and sensual pleasure. Second) is a rational political power that allows everyone to satisfy personal interests, worldly and to prevent crime according to rational principles. Third) is a political power based on moral (siyasa diniyah or caliphate) to enable more people to the welfare of the world and the hereafter in accordance with the teachings of the Shari'a. If someone wants to use a modern term for three types, that person can call laissez faire or passive state secular, secular welfare state, and welfare Islamic state or caliphate. Third) is a political power based on moral (siyasa diniyah or caliphate) to enable more people to the welfare of the world and the hereafter in accordance with the teachings of the Shari'a. If someone wants to use a modern term for three types, that person can call laissez faire or passive state secular, secular welfare state, and welfare Islamic state or caliphate. Third) is a political power based on moral (siyasa diniyah or caliphate) to enable more people to the welfare of the world and the hereafter in accordance with the teachings of the Shari'a. If someone wants to use a modern term for three types, that person can call laissez faire or passive state secular, secular welfare state, and welfare Islamic state or caliphate.

If God is one, then the man is also a creature that should reflect on the purpose. The distinction made by the concept of thought, race and skin color, and that is the thinking of human brotherhood. Qur'an is reflection of the brotherhood of man. Clearly states that people are created as one nation (ummah) but become divided because of the difference of their own creation (al-Qur 'an 10:19). Conflicts of interest, prejudice, exploitation and abuse of power has taken its toll in the breaking of the human race. However, the ultimate goal of Islam is to reunite all of them (al-Quran, 11: 119) There are several ways to achieve integration of mankind. One of them is the creation of a better understanding between people through greater interaction and cooperation with a view to eliminating, or at least reduce, the prevailing prejudice, and misunderstanding that lead to conflict. Since economics plays a dominant role in human life, the process can be accelerated if the economic integration among countries in increasing mutual dependence and interact positively. through, labor, technology and information (Chapra, 2015).

It is important for the welfare state in Islam is how do we ensure that everyone follows the teachings of sharia in their worldly affairs. Political or state powers $(G)$ shall establish Shariah efficiently make the laws and regulations to ensure fairness and implementsi of Shariah. Then carry out development (g) and create kemakmuaran (W) kapada community $(\mathrm{N})$ who understand the Shari'ah (S). Seen a dynamic cycle between all these variables, known as the circle of cause and effect. 
Long-term analysis of this formula states that no ceteris paribus clause because no one variable constant. One variable or component may serve as a trigger mechanism but variable or other components can react or not, in the same direction.

The form is the cycle shows that a Muslim society can only choose from which components will begin, it's just that people should understand the consequences of his choices. A Muslim community who took component Shari'ah Shari'ah and prioritize study will be compelled to change of organization studies Organiasai Shari'ah into human resource development, for example through the missionary movement which would then be compelled to increase wealth. So there is a change of organization missionary movement into an organization's economic movement. Next will be encouraged to think about the development of other sectors and law enforcement. Furthermore, it will prompt the establishment of a caliphate. This process is called the process of gradual Islamization of the economy with the cultural approach,

Models of the dynamics of socio-economic Ibnu Khaldun enhanced by Chapra into a cycle of cause and effect progress and setbacks of a civilization, nation or state can be a straight line and very straight that economic development for the welfare of society can not be separated from the five other variables which one another dynamically related.

Therefore, by studying historical Indonesia, which then reflected into the cycle of cause and effect progress and setbacks of a civilization or this country is the subject that will be worked in this study.

\section{Research Methods}

This study uses qualitative data focused on a comprehensive description, classification data and linkages between the concept of qualitative research is related to the meanings contained in the social process, which can only be understood in accordance with the cultural context. Meanings emerge when we find various symbols, artifacts, behaviors, attitudes or non-verbal languages that exist around the subject, classification of qualitative research consisted of words and actions. This study uses secondary data (Moleong, 2014).

Secondary data is an answer to the fears in the form of qualitative writing stories or notes about an event that was not witnessed by the reporter. The main data source of this research is statistical Book Indonesia (statistical year book of Indonesia), BPS, Indonesia's foreign trade statistics, and International Financial Statistics. Research libraries in Indonesia is done by studying books or sources of data and population 
growth, the economic history of Indonesia, Indonesia's political development, and a biography of the president of Indonesia (Martono, 2010).

In this study, the authors combine qualitative historical research. The historical method of research lies in the range from 1945 to 2016. The qualitative method of the issues for discussion reflected the economic field which uses historical facts, without intent to generalize to cases in other Nation, and do not attempt to test a hypothetical. The nature of this research is descriptive, which describe in depth about the situation, or the process under study.

Kuntowijoyo (2001) states that the study of history has five stages, namely the selection of topics, gathering resources, verification (historical criticism, the validity of the source), interpretation (analysis and synthesis), and writing. Topic selection is to determine the title of the issues to be studied. Topics to be studied, should be based on emotional closeness and intellectual closeness. This study is a literature or literature so that the resources collected are written.

Kartodirdjo, S., \& Pusposaputro (1992) stated that external criticism and internal criticism in the science of collecting historical materials collection and completion technique is an indirect observation data. The sources used by most authors is the books that have been available in libraries and bookstores Malang. The number of books available cause variations in writing, the use of foreign languages in the book and the determination of the number of years an event. Therefore, the authors attempted to be intersubjectively the books that will be used as a reference in the writing with based on the collection of data that occurs when the event. Interpretation is an interpretation by the author within the meaning interrelated set of economic factors and history. In this stage, the authors seek and define the meaning obtained after a specified external and internal criticism. Based on the meaning of the external and internal criticism, then assembled into a form that can be delivered and can be verified.

\section{Results and Discussion}

\subsection{Reflections on revolution phase until the end of the old order (1945-1966)}

Towards the Proclamation of August 17, the debate about how the state of Indonesia will take place with a lot of class Nationalist secular and class Nationalist Islam in determining the basis of the country of Indonesia. Debate and this conflict can not be reconciled. Secular nationalists still want to separate the affairs of the state of affairs of Islam and 
og the Islam adamant to defend what he stood for. Condition when it was how in the ideological debate is the strength of Islamic groups in BPUPKI quantity is only $20 \%$ while in terms of quality in philosophical argumentation lost much of Ir. Sukarno and his friends. Finally, agreed to form a "Committee of Nine" (Noer, 1987).

The long process of discussion and debate resulted in a compromise reached on June 22, 1945 by adding seven words in the first precept to becoming "Godhead with the obligation to carry out Islamic law for its adherents". This concept is called the "Jakarta Charter". It was agreed that the basis of the state was the Pancasila with the first precepts read as mentioned above. Other Islamic demands are the stipulation that the head of state must be Muslim and the sentence "the obligation to carry out Islamic law in the constitution is included.

Actually, if you are more observant about the series of struggles of Islamic leaders, is it true that they want Indonesia to become an Islamic state? The answer is actually no. Because, the ideas of Islamic leaders make the basic Islam of the state actually not equipped with empirical arguments about the "Islamic state" that is aspired. Viewed from this point of view, what is actually being fought for by Islamic figures in BPUPKI and PPKI is not the realization of the concept of an Islamic state but more precisely the guarantee of the implementation of Sharia Islamic teachings. Of course, the guarantee is that this country will stand.

A common thread that can be taken is the Islamic leaders who also include founding fathers from this country have never seen the form but are more inclined to substance. The most important thing is how the state functions in guaranteeing the establishment of an Islamic system and for creating prosperity and protection for its people. The state as one of the operational bases in manifesting Islamic teachings was also carried out. It doesn't need to be the name or emblem of Islam in the country. Indonesian Islamic State for example.

Whether what he had in mind the figures of Islam as it is, but one thing is apparent that they are well aware of the function of the state in ensuring the rule of law for Muslims who are filled almost all places in the new Republic. This consciousness is actually the result of Islamic education they of receive. Education gave doctrine upon themselves the perfection of Islam. Education also emphasizes that the enforcement of Islamic governance is one of the principles of Islamic aqidah or obligation so that in their minds there is no separation of religion and state. In contrast to the secular nationalist figures who graduated western materialistic philosophies which are so dominant in themselves although they can not deny the religion itself. So it is true, will never meet the characters 
graduate schools, junior secondary and senior high graduates with figures Mulo or HIS let alone ever get education in Europe at the time.

Ibnu Khaldun says that Islam is the state or a state government that "Islamic welfare state" (siyasa diniyyah or caliphate). Islamic welfare state to strive for everyone to follow the teachings of sharia in their worldly affairs. State $(G)$ should keep an eye on all behavior which could endanger the socio-economic development such as dishonesty, fraud and injustice. Countries must also ensure compliance aqad and respect for property rights and create awareness to the public prerequisite qualities necessary for development and social harmony based on justice.

This is actually desired by Islamic leaders. They actually do not want the Caliph as the days of the Apostle for instance, or the kings in the days of the dynasties of Islamic or feudal system of Islamic empire that ever existed in the archipelago. So as any form of state offered by the secular nationalists with a variety of underlying philosophy and all of it if there is no guarantee the enforcement of Shariah in accordance with Islamic welfare state, more likely to be accepted by the leaders of Islam at the time. Indication is strong and it is evidenced by the charter Jakarta, although the foundation of the state is not the Qur'an and Sunnah, but there is no guarantee that through the first principle.

Economic model of Ibnu Khaldun said that the Shariah has proven its strength as the glue that holds the community at large. Syari'ah help people $(\mathrm{N})$ instill kindness qualities like obedience, honesty, integrity, humility, and a sense of community that can contribute to the development process, justice, mutual understanding, cooperation, peace and harmony as well as controlling behavior that can endanger the public.

Values like this is living in the Indonesian society at the time and because of the love of liberty and freedom efforts have been made to defend the country and homeland. Seen in Indonesian society, Shariah live in them and become an integral part of the system even though the state does not guarantee this enforcement. Society is filled by the values of Shariah this is an asset for the country and is a wealth of resources as said Ibnu Khaldun "authorities will not be able to obtain power but of society."

Chapra cycle to temporarily stop the public $(\mathrm{N})$ and could not continue the cycle next to the components or variables that achieve prosperity or wealth (W). Potential society today is how to maintain the independence of the country, so that the future economic development can not be implemented. At that time, the economic situation is so bad that economic reconstruction could not have been held.

An economy that marked this period is the development of very high inflation. Sources of healthy spending limited. Budget deficit is the main cause of inflation. Printed money 
very much. Nearly $50 \%$ of state expenditures covered by printing money that is expected to nourish the monetary sector, but it failed. A large state budget deficit is not dammed.

Another thing that marks this period is the instability of the balance of payments. Comparison between surplus and the current account deficit is very large (greater deficits). The current account deficit and long continuous adversely affect inter alia, on the development of rupiah exchange rate continued to decline and foreign exchange reserves continue to decline. The instability of the balance of payments when it comes to the burden of foreign debt. Although debt and foreign aid (foreign aid) can not be accepted by natural thought guided economy, but the government at that time foreign debt inherited from foreign countries ranging from Communist countries, the West, and Asia.

Developments end or culmination is the economic turmoil (economic chaos) until the fall of this regime. Again, the "mirror" of Ibnu Khaldun's socio-economic dynamics can be "used". The important role of the state contained in the causal circle which was sparked by Ibnu Khaldun, the state does not have the character of a monolithic or despotic state which constantly controls people's lives strictly. The government should not exercise absolute power for personal gain. The government is also not allowed to act arbitrarily because of the power holders. The government should use its power to make the function of the market run smoothly and to create an environment that supports the realization of development and justice. Ibn Khaldun clearly stressed the importance of the role of private companies and the state in economic development, meaning that there is a balance here.

His reflection for this period is roughly to say that according to this cycle, the government suffered a setback, the government did not carry out its functions as expected, accountability and obligations were not carried out at all. This has led to a loss of justice and a breakdown in development marked by the mounting social and political power of the people by crippling political parties. All of this results in the loss of freedom of opinion so that the people can no longer criticize the authorities and discuss government policies openly.

As a result, the cycle continued to retreat with the endless wealth of the country and society and prosperity will be lost. Financing military activities so high at that time coupled with high foreign debt. This condition weakens communities. When a weak society means that people no longer motivated to do their best and to improve its quality. Shariah underlying thought pattern will not end the implementation of Shariah society becomes far from the shadow. 
The weakening of the public will be followed by the weakening of the state and the loss of political power of the country that ended in the collapse of the regime which is then accelerated through a coup G 30 S / PKI. At this time Indonesia suffered a setback cycle.

\subsection{New order phase (1966 - 1998)}

The New Order government never acknowledged that the Indonesian state was a secular state but the characteristics of a secular state colored some of its policies. The New Order also never acknowledged that the economic ideology adopted was liberalism or capitalism and socialism, namely by recognizing and protecting that all were based on Pancasila. The essence of the new order substantially adopts these two values. This indication is evidenced by the achievements of economic growth that do not necessarily increase the welfare and prosperity of the people, but many other costs that must be paid by the government are certainly diseases caused by the characteristics of capitalism, including the symptoms of anomie that arise in society. Another indication of using the military is that the government has indirectly "forced" the people to accept ideas and desires that are truly unacceptable to the people. This causes tension and damages relations and solidarity between the authorities $(G)$ and the people $(N)$.

The process of community transformation that is claimed to be modern turns out to change the structure of society which is full of Indonesian cultural values based on Islamic values shifting to modern values, which is more precisely "western". How smart are foreign investors or investors in Indonesia to change this. They knew that Indonesia was fertile land and agriculture was a suitable area for it. But with the various theories that underlie the most famous is the value added to lead to growth, the concept of industrialization in all fields is recommended. The industry needs large capital and the capital is in them. Then what happened was exploitation of natural resources by them and the lucky ones of these investors so that Indonesia only got one of the diseases of the capitalist system, the Indonesian nation only became a working class. Finally, fertile land was replaced with industry which led to the transformation process of Indonesian society which tended to be agrarian in the countryside absorbed into workers and laborers in factories.

Development thinking of (Djojohadikusumo, 1994) They consider the people of a country still underdeveloped in the arrangement of the economy where about $80 \%$ of the population lives workforce earning money from the primary sector (mainly from agriculture, fisheries, and livestock). Transformation of society towards an advanced 
economy characterized by reduced people depend on the life sector, namely the primary sector from $80 \%$ to below $15 \%$. A transformation with the shift of economic activity from agriculture to sectors outside of agriculture that impacts multiple (Multiplier Effect) in the economy of society as a whole. To improve the economy of developing countries is needed aid from developed countries (donors). Donor countries have wanted the assistance provided is intended for projects that are useful to improve people's lives a little and not for things that are not useful. Donors also want real results from this aid.

Thought that underlie development in Indonesia and for industrial development (industrialization) This has led to increasing levels of poverty as a result of the increasingly widespread unemployment due to the reduction in productive employment in the agricultural sector and not maximal capacity of labor in the industrial sector is still at the stage early. Rapid economic growth it can bring a community into a state which is too unstable. This is because the economic changes quickly will bring consequences that are not simple for people to remember association with many sectors and elements of society that is very complex. Unless the sectors and sections of the society are able to make adjustments before the changes happened quickly (Siregar, 1991).

But at the time, it just became obiter dicta, that statement only last traffic at that time were so stunned with growth theory. Ibnu Khaldun says that one of the functions of the state is to create or promote science and Industry (al-ulum wa al-Sana'i). That is, there is nothing wrong with the industry, it will accelerate the process of the Development industry forward. The underlying difference is the basic paradigm of the developmentalist why should industry. The industry does not have to transform society until he lost his spiritual needs. Industry also do not have to change the structure of society does have its own characteristics and only need development and not change. Working in the field of industry is not the standard that was developed or modern. Precisely according to Ibnu Khaldun tarbiyah or pendidikanlah that makes a person or the community forward, so that in the mind of Ibnu Khaldun to promote Science and Industry (al-ulum wa al-Sana'i) is simultaneous to do. New Order regime when it should have been more focused on community development by educating not just "fill his stomach". Non-growth programs should be more dominant at the time.

In the economic field, this period was marked by a sluggish and difficult period due to the world recession. The presence of external factors or known as external shock influenced the growth of the Indonesian economy at that time. As a result, economic growth has declined or better known as low and slow growth. Indonesia, which has received a loan from abroad when it wants to return, must drain a large amount of the national budget. 
The influence of being too focused on development has begun to be "felt" by the government at that time. As anticipation, the government stressed the concept of the Development Trilogy in its development strategy and meanwhile foreign loans with soft loans continued to flow. Complementary to this development trilogy, the government triggered the "Eight Paths of Equity".

An oddity and paradoxical occurrence occurs when Indonesia has "felt" the negative effects of focusing on growth, the government actually follows the prescriptions of the World Bank and the IMF known as growth-oriented adjustment programs. This recipe requires the government to make economic adjustments oriented to economic growth in order to get out of recession. Once again growth, there are four things offered, namely, mobilizing domestic funds, promoting investment, promoting exports and realizing efficiency in economic diversification. This recipe is also supplemented by deregulation and privatization policies. This was followed by the government so that equality was heralded only by "mere service" lips.

The results of the IMF prescription is then said to have been successful in restoring financial stability and restore economic growth. However we see and we noticed this recovery is temporary and does not fix the basic or fundamental to the country's economy. The level of dependence on external conditions are still very high. That is, this recovery factor is the main cause of the improvement in external conditions in this case the world economy. Threat of economic collapse could happen at any time and this recovery could be lost in the wind because the economic fundamentals are not strong built and more on borrowing from abroad injection and so dominant external influence.

Indonesia's economic growth is rapidly increasing with the monetary sector that is so dominant in the late 80's decade. Indonesia is the country with the largest amount of debt in the world's top four. The debt management for the construction fund is not at all effective, many a leak here and there due to the corruption that became a common behavior and as if invulnerable and invisible by law. Surely this is an indication of the end of the triumph of the new order and the beginning of the country's economic downturn in the next period (Budiman, 1991).

Socio-economic dynamics models Ibnu Khaldun who returned to become a "mirror" in analyzing this phenomenon states that the state should not try to carry out its role with violence and oppression. Instead he emphasized the good government and wise, strive for the welfare of society and accelerating the growth of creativity and community development activities. Therefore, the government should put a major force in the education community. It is the people in fact is the strength of a country. 
During the second decade of the new order of government power is not public. Society made opponents and enemies so that the relationship is full of suspicion that led to acts of violence if someone tries to dare oppose, criticize or obstruct government programs. The basic power for political stability and security, namely the military and bureaucracy coupled with Golkar were so dominant. As for the construction of an injection or injection obvious from abroad is more prevalent.

Creativity of the community who participate in the development process is very less to be fostered. Government more confidence to foreign powers in the order of the concept and help than the people themselves. This leads to results that are not spread evenly. The group that did not receive the results of this uneven development is the community. Symbolic

Equalization with eight lanes Equityonly stayed a concept on paper let alone the name of economic justice did not exist. Inequality, inequality and economic injustice more so where wealth is only a group of people known as the conglomerate. Naturally, if the community can not stand by these conditions, public confidence in the country will be lost.

The opposite condition occurs after the economy enters human welfare in this broad sense, so economic tasks can be broader and more difficult and complex, including moral, psychological, social, political, demographic and historical, which determine welfare in a comprehensive sense. It may also be necessary to answer a number of questions that might not need answers if the aim is only to help maximize wealth and consumption in the community. One of these questions might be whether the portion of interest would be sufficient as a motivating force to realize comprehensive well-being, or it would also be necessary to have several other driving forces. Can such welfare be realized more effectively if all agents operating in the market observe certain rules. This is because individual freedom is also important for human welfare and cannot be compromised except to a certain extent Individual agreement (Chapra, 2000).

Beginning in the 90s, economic growth in Indonesia was very high, to the point that Indonesia was called miraculous but still brought old homework such as foreign debt that was increasingly high and unfinished. If it is not finished, then the destruction will be suffered by this nation. Homework has emerged, namely preparation in facing global competition in this case is economic globalization. New problems for efficiency and productivity emerge.

Early 90s also occur very complicated issue, namely the issue of Over Heating economy because growth is so big and tall. This was also followed by the current account deficit of the state budget from year to year is severe enough to threaten the 
foreign exchange reserves, the rupiah exchange rate, payment of short-term foreign loans. Additional costs incurred due to over heating are the high inflation caused by rising investment and consumption is so high that the monetary expansion could not control.

The other side in the socio-economic field behavior of KKN (corruption, collusion and nepotism) is very interrelated and a culture which is an acute disease that is difficult to cure. Network corrupt bureaucracy built by the government was so strong that the village level so many costs that are not effective due out this corruption behavior trends. High economic growth is one of the causes of this, because people tend to be spoiled and creativity are not formed so that the high consumption behavior so dominant and certainly when they need income high consumption are numerous and tend instant, then there's corruption. New Order government forgot to discipline even inclined to let the state budget due to ineffectiveness of the supervisory function properly. The projects are mostly financed from abroad are not effectively monitored even rarely any evaluation of its existence. Corruption, collusion and nepotism prevalent in many fronts.

Midlle 1997, Indonesia experienced a severe financial crisis, and even then the nightmare began. System and the foundation that was formed 30 years ago won the day now backfired for this regime. Came the calamity that is very devastating the Indonesian economy. Economic growth had been so high that eventually had to fall and as if lost. Various policies adopted by the government but simply could not recover the situation.

This crisis comes from the turmoil that hit the foreign exchange market as part of a regional financial panic that the onset of shock exchange rate Baht (Thailand). A shock from the outside (external shock) back open sores Indonesia in the form of weak banking sector and economic structures that operate in the socio-political system that displays false stability and sturdiness.

This crisis developed into a severe economic crisis. Through a process with contagion effects, this surprise hit extends banking, investment, production, trade, consumption or real sector of the economy so that the entire economy national crisis. Finally, the crisis continues on socio-political sector so that this process raises a comprehensive and multidimensional crisis (Djiwandono, 2002).

As it turned out, the foundation or foundation of the country's economy was not strong, it revealed that so far what had happened was only Bubble Economic and it broke out instantly. The entire economic structure collapsed and added to coincide with maturing foreign debt to complete the suffering of the people and the country. Many people suddenly fall into poverty, unemployment increases and appears instantly. 
Even worse, inflation spreads to basic necessities or basic necessities that are directly related to the community.

On the political front, 1997 was also marked by the General Election win back Golkar so that President Suharto was re-appointed. Amid the nation that profanity and disorderly president Suharto economy can not resolve the crisis and can not effectively manage government then take shortcuts to increase aid or foreign debt. President Suharto signed an agreement with the IMF. IMF-entered with a "mask" to help Indonesia out of the crisis, the Indonesian economy became ruler armed with a piece of paper known as LOI (Letter Of Intent).

Increasingly ineffective state management, the stabilization program was not fruitless. Condition increasingly chaotic country. Crush of life difficult to meet the basic needs makes people lost patience and be no longer trust the government anymore. Came anarchy peoples known as riots of May ' 98 where there is massive looting in Jakarta.

Given these circumstances students took to the streets and occupied the MPR / DPR forced President Suharto to step down. May 21, 1998 ended the New Order regime. No previously predicted the sudden authoritarian regime that has ruled the 32-year submarine finally had to fall from his throne. Evidently, that the authorities can not obtain power but of society (ar-Rijal).

Injustices of politics or government authorities and a very high level of development which will lead to corruption (facade) in society and the destruction of (ruined) civilization due unbuilt maqashid ash-Shariah. Further development results will not be spread evenly. Dispersing the uneven development that will reduce the working spirit and creativity of the lower level so that the level of prosperity will deteriorate over time.

Furthermore, in the body of society will also be the desire to do the moral corruption and easing restrictions in terms of consumption patterns. The attitude of the simple life will fade, wasteful attitude will emerge. Society tends to spend their income on luxury goods. When they are not able to fulfill these desires in ways that correct then commit corruption of their choice. Finally, the values taught by the shariah will be lost and the Shari'ah no longer effective in shaping society and its implementation would be utopia.

This has not stopped here because the cycle starts from the government, it will have an impact on the government or political authorities. The decline in income also resulted in a decrease in tax revenues which ultimately was not enough to cover state spending. Even though the country will experience obstacles in development, the economic recession will also increase and destruction will accelerate so that the ruling government will fall. This is a cycle of setbacks if we refer to the Chapra cycle. 
Indonesia has proven part of Ibnu Khaldun's thesis is that the other side of this thesis is the cycle of progress is likely to be applied. Obviously how non-economic factors or other sides so affect how the progress and decline of a nation. This model is more easily analyzed and the relationship between one variable to another variable that could easily be understood.

However, there are some records that may be when Ibnu Khaldun wrote Muqaddimah there has been no case of the issue of foreign loans or debt. This is because when Ibnu Khaldun wrote his thesis, Islamic civilization when it would start a setback though there has been no rival. That is, when the civilization of Islam that ruled the world and the west when it has not been anything was going to start a revival. So that no foreign loans from other countries, because even other countries are as advanced no Islam at the time. But now the western countries in this regard is the United States and Europe coupled with some Asian countries such as Japan, China and Korea are considered to be more advanced and the other so-called third world countries and generally are the countries where the population is Muslim.

Basically the same, according to the government of the destruction of the deterioration cycle finishing touch her there a decrease in state revenue that is no longer enough to cover state spending. The Nation will experience barriers to development, economics recession will increase and the destruction will occur more quickly so that the present government will fall. Ibnu Khaldun just look at the causes of decline in state income taxes only on the decline due to declining quality people that are the result of a chain reaction of the previous cycle.

Now, because of a decrease in state revenue, the government tried to borrow or owe to foreign or donor countries that it if it can not be restored from the reception the other will make the country into bankruptcy alias collapse and economic recession happens, governments fell. The core difference is the addition of an error in the quality of government. Already know less in terms of revenue and then borrow but can not return.

When viewed more deeply with the priorities of the New Order economic development and growth has been ignoring the four other components of the cycle of progress and setbacks. Finally, the administration proved it did not last long.

\subsection{Reformation era}

Indonesian state was tested by God. The collapse of the New Order regime whether it can be used as a turning point for Indonesia's future progress, a challenge for the 
new goverment this transition. After President Suharto Fall from power, he was replaced by his deputy that President BJ Habiebie. The daunting task to be shouldered by the president in this transitional period. The main thing that is done by this government is to restore public confidence that has been lost and coupled with foreign restore confidence lost as well. To restore public confidence, the government put a pragmatic strategy that directly meet the immediate basic needs of society to subsidize and provide non-budgetary funds directly to the public.

These policies were based on the thought or discourse that developed as the antithesis of the economy which is only held by a group of people alone in this regard is a conglomerate. This system is known for the economy and its icon is Adi Sasono as a minister in the cabinet Habiebie.

Monetary policy side, the government is trying to restore public confidence in the banks that also collapsed due to the crisis by means of state guarantees the public's money at the time and tried to keep the rupiah against the dollar can be relatively stable and strengthened.

Government in restoring confidence abroad in order to remain willing to invest their capital in Indonesia the government is trying to cooperate with a show characterized as democratic governance and simplify the state bureaucracy. Government in making this ill afford to have to remove East Timor from Indonesian lap, because the poll results indicate Teams society to escape from the Indonesia.

Politics, this government has a tough task of holding elections were really democratic elections in which the target is implemented in 1999. In the political pressure and to claim the complex society in which people at the time of this reform is not timid again criticized the government and even too "free "this administration works. Efforts to restore public confidence that the state back strongly didasarinya with weak accountability when it. So the government is trying to restore it.

The study of history shows that modern democracy can only occur under certain conditions of capitalist industrialization. Karl Marx identified the bourgeoisie as the main force behind the emergence of democracy. He argues that the capitalist class uses a parliamentary system and democratic mechanism to capture control of the state of the traditional elite (Arat, 2011).

However, a final assessment of these efforts shows that the government has not succeeded in restoring accountability. This is evidenced by the rejection of the President's accountability report at the general assembly in 1999. The image of a new order is still considered attached to this administration. President BJ Habiebie still be seen as an extension of the previous government and society still traumatized because 
of it in addition to the president's political enemies. As a result, this short-lived finally Government had ended and their duties to the state drove of democratic era he finished with the end of the 99 th general election that really showed the political configuration of the people and the people of Indonesia.

Several lessons can be drawn from this period through a "mirror" that always we use to analyze the phenomenon. It would be very dangerous if people already do not trust the government anymore. Loss of justice (j), which is practiced by the new Order are likely to cause dissatisfaction among the people $(\mathrm{N})$, discouraging community and adversely affect community cohesion. So once trust is lost is very difficult to restore it. What it means a government that is totally supported by the people. The transitional government has no other forces as the first new Order has a military and technocrats for the military at this time did not dare to reappear and prefer to remain silent in advance.

Furthermore, during Abdurrahman Wahid's reign, several lessons could be taken from this period of government through a "mirror" model of Ibnu Khaldun's socio-economic dynamics. It is not possible for the government to impose a policy without considering the interests of the community, because this will eliminate community solidarity $(N)$ for the government $(G)$, which in turn will create chaos and create conditions that are not conducive to development. If people feel alienated by their government, the government loses support from the grassroots, which in turn the government will not last long. This is what happened to the government of President Abdurrahman Wahid. The point is that there is still public trust which is the strength of the state again proven "The ruler can not get power except from the community".

The reflection in the reign of Megawati, Susilo Bambang Yudhoyono and Joko Widodo indicate a repetition of the same pattern so that the discussion will be a reflection of this will be repetitive as the same as before. Mirrors used will be "broken" and becomes useless if used continuously for the same thing and there is no change there. So, using reflection of economic development through social dynamics model of Ibnu Khaldun sees the rise of the Indonesian state seems still difficult to achieve.

\section{Conclusion}

Reflection begins with the period when Indonesia gained independence until the expiration of a period called the Old Order. That period was marked by the debate on the base of the state and where Indonesia's future should be taken. Some of the founding fathers of Indonesia tried to start a cycle of progress in the Shariah point by trying to incorporate elements of Shariah in the areas of state as a guarantee of enforcement 
of Islamic Sharia in Indonesia. But this attempt failed and not been able to penetrate areas of the state due to hit the ideological war with the secular nationalists as rivals. Syariah stay alive in the midst of society and becoming a major power in defending the independence of Indonesian society. And the cycle stops at state point $(G)$ only.

In the second half of this phase is characterized by a very dominant role of the state after the power of the people represented by the political parties paralyzed as a result of a very long debate on the basis of the state that was dissolved by the President at the time. The state becomes the center of everything ranging from economic, social, political, cultural, defense and security. The state becomes a monolithic state, resulting in a cycle into a retreat that started from the Government (G). Then justice does not exist, followed by the construction of a stagnant ( $\mathrm{j} \& \mathrm{~g}$ ) resulting in depleted state assets so that society is becoming weaker and lead to utopia enforcement of Shariah so that the state is also becoming weaker. Finally, this period is closed with a rebellion G30S / PKI is causing this regime collapsed.

The end of the Old Order brought great hope for a turning point towards the cycle of progress. The architects of the New Order turned out to choose a turning point on the wealth variable to lead to development and poverty. However, the element of justice is not so dominant in their minds. In the 50s and 60s the economists who built the architects of the New Order not only ignored justice but also emphasized growth. They also forgot the logical consequences of leaving behind the factor of Shariah and society. They argue that the redistribution of income that benefits the poor is unlikely to increase economic growth in the sense of greater per capita output. Their view is that distribution for the poor will only be achieved if growth can be accelerated. In such conditions what happens is very popular known here as the tricle down effect.

Reality proves otherwise. Tricle down a powerful weapon in defeating to attempt growth up in countries where a lack of attention to eliminate justice. Indonesia is one of the tasting. Former President Soeharto was in power during the hatching convinced concept down will be a tool of distributive justice. Therefore, he argued there is nothing wrong if the country in economic orientation is more concentrated on efforts to accelerate and sustain economic growth. He did not hesitate, despite the economic held by a handful of entrepreneurs who continue to be facilitated and pampered government. Came the conglomerate because only conglomerate that get the most attention and be the economic engine of the nation. But, what happens beyond the shadows and hope, What is left of the crisis that continues to plague this country? At least we note a number of fundamental problems of our economy due to the accumulation of economic injustices so far in the form of: severe structural poverty, exploding unemployment, 
inequality of income distribution, inter-regional development inequality, concentration of ownership of productive assets in conglomerates, foreign debt burden and colonization of the national economy by foreign powers. Not surprising, because what the New Order economic architect team is proud of with the concept of the tricle down effect and the pursuit of economic growth as high as possible is nothing more than the achievement of an artificial bubble economy. 'The lost economic miracle', might be the right sentence to describe how our economic fundamentals are indeed weak when a storm of economic crisis hits this all country

This will weaken the community and when the community is weak happened countries will also be weak because of the loss of public trust and public confidence is lost if the government in power will fall by itself. As evidenced by the fall of President Suharto without previously suspected.

There were great expectations when Indonesia entered the reform era to reach the turning point towards the cycle progresses. A democracy that opens a new hope. Shariah enforcement voices have also begun to be heard everywhere. However, it seems the people of Indonesia are still in a test of patience because until recently the progress coveted and it is real and not a false progress seems still far short of expectations because to date there is no sign of the direction there. Today, almost all elements of the government from the executive and legislative branches and the entire government bureaucracy is entangled elements of corruption and concern themselves with any group or party and society as a tool of legitimacy and sheer utilized. If this pattern continues, it is clear the level of economic prosperity (W) community will shrink due to the explosion of the number of poor and unemployment rate, quality of personnel will decrease $(\mathrm{N})$, which can result in lost public confidence to the government.

\section{References}

[1] Arat, Z. F. (2011). Democracy and Economic Development Modernization Theory Revisited. JStore.Org, 21(1), 21-36.

[2] Bin Khaldun, M., \& Abdurrahman, A. A. (2011). Mukaddimah Ibnu Khaldun (Tiga). Jakarta: . Pustaka Al Kautsar. Retrieved from https://books.google. co.id/books?hl=en\&lr=\&id=zXTtDAAAQBAJ\&oi=fnd\&pg=PR24\&dq=ibnu+ khaldun\&ots=6hvCGOIMZb\&sig=94O6dLOd28LZcKvalWfNvmbknLc\&redir_esc= $\mathrm{y} \# \mathrm{v}=$ onepage $\& \mathrm{q}=\mathrm{ibnukhaldun} \& \mathrm{f}=$ false

[3] Budiman, A. (1991). Negara danPembangunan, Studi Tentang Indonesia dan Korea Selatan. Jakarta: Yayasan Padi dan Kapas. 
[4] Chapra, M. U. (2000). Is it necessary to have Islamic economics?? The Journal of Social-Economics, 29, 21-37.

[5] Chapra, M. U. (2007). Ibn Khaldun's theory of development?: Does it help explain the low performance of the present-day Muslim world?? ?. https://doi.org/10.1016/j. socec.2006.12.051

[6] Chapra, M. U. (2015). Islamic economic thought and the new global economy. Islamic Economic Studies, 09(May).

[7] Djiwandono, S. (2002). 80 Tahun Mohamad Sadli Ekonomi Indonesia di Era Politik Baru. Jakarta: Kompas.

[8] Djojohadikusumo, S. (1994). Perkembangan pemikiran ekonomi: dasar teori ekonomi pertumbuhan dan ekonomi pembangunan. LP3ES.

[9] Hasyim, H. (2012). Watak Peradaban dalam Epistemologi Ibnu Khaldun, 22(3), 2012.

[10] Kartodirdjo, S., \& Pusposaputro, S. (1992). Pendekatan ilmu sosial dalam metodologi sejarah. Gramedia Pustaka Utama.

[11] Kuntowijoyo, M. T. M. (2001). Esai-Esai Agama. Budaya, dan Politik dalam Bingkai Strukturalisme Transendental. Bandung: Mizan.

[12] Mahyudi, M. (2015). Reviving the Islamic economic system through shariah-based public policy. Humanomics.

[13] Martono, N. (2010). METODE PENELITIAN KUANTITATIF: Analisis Isi dan Analisis Data Sekunder (Edisi Revi). Jakarta: PT. RajaGrafindo Persada.

[14] Moleong, J. . L. (2014). Metodologi Penelitian Kualitatif. Bandung: PT. Remaja Rosdakarya.

[15] Noer, D. (1987). Partai Islam di pentas nasional, 1945-1965. Grafitipers.

[16] Rikmat Ismatullah. (2009). DINAMIKA SOSIOEKONOMI PADA ILMU EKONOMI ISLAM KLASIK. JURNAL LITERASI, 37-44.

[17] Sholihin, A. I. (2013). Buku Pintar Ekonomi Syariah. Gramaedia Pustaka Utama. Retrieved from https://books.google.co.id/books?hl=id\&lr=\&id= 3F5nDwAAQBAJ\&oi=fnd\&pg=PP1\&dq=Adiwarman+syariah+di+bidang+Ekonomi. \&ots=lyHCQRCYt2\&sig=InLSWAX1FNwayQmdgFTkMrGZOYY\&redir_esc=y\#v= onepage\&q=AdiwarmansyariahdibidangEkonomi.\&f=false

[18] Siregar, A. E. (1991). Arus Pemikiran Ekonomi Politik. Yogyakarta: Tiara Wacana.

[19] Bin Khaldun, M., \& Rahman, AA (2011). Preamble Ibnu Khaldun (Three). Jakarta: . Reader Al Kauthar. Retrieved from https://books.google.co.id/books?hl=en\&lr=\&id= zXTtDAAAQBAJ\&oi=fnd\&pg=PR24\&dq=lbnuu+khaldun\&ots=6hvCGOIMZb\&sig= 
9406dLOd28LZcKvalWfNvmbknLc\&redir_esc=y\#v=onepage\&q=IbnuuKhaldun\&f= false

[20] Budiman, A. (1991). State danPembangunan, Studies Indonesia and South Korea. Jakarta: Yayasan Rice and Cotton.

[21] Chapra, MU (2000). Is it Necessary to have Islamic economics? The Journal of SocialEconomics, 29, 21-37.

[22] Chapra, MU (2007). Ibnu Khaldun's theory of development: Does it help explain the low performance of the present-day Muslim world? ?. https://doi.org/10.1016/j.socec. 2006.12.051

[23] Chapra, MU (2015). Islamic economic thought and the new global economy. Islamic Economic Studies, 09 (May).

[24] Djiwandono, S. (2002). 80 Year Mohamad Sadli Indonesian Economy in the New Political Era. Jakarta: Kompas.

[25] Djojohadikusomo, S. (1994). The development of economic thought: the basic economic theory of economic growth and development. LP3ES.

[26] Hashim, H. (2012). Character Civilization in Epistemology of Ibnu Khaldun, 22 (3), 2012.

[27] Kartodirdjo, S., \& Pusposaputro, S. (1992). Social science approach in the methodology of history. Gramedia Pustaka Utama.

[28] Kuntowijoyo, MTM (2001). Essay-Essays Religion. Culture, and Politics in Frame Transcendental structuralism. Bandung: Mizan.

[29] Mahyudi, M., Mahyudi, M. Hassan, S., \& Said, J. (2015). Reviving the Islamic economic system through shariah-based public policy. Humanomics.

[30] Martono, N. (2010). QUANTITATIVE RESEARCH METHODS: Content Analysis and Secondary Data Analysis (Edition Revi). Jakarta: PT. RajaGrafindo Persada.

[31] Moleong, J.. L. (2014). Qualitative Research Methodology. Bandung: PT. Youth Rosdakarya.

[32] Noer, D. (1987). Islamic party on the national stage, from 1945 to 1965. Grafitipers.

[33] Rikmat Ismatullah. (2009). Socioeconomic DYNAMICS IN CLASSICAL ISLAMIC ECONOMICS. JOURNAL OF LITERACY, 37-44.

[34] Sholihin, Al (2013). Book Smart Islamic Economics. Gramaedia Main Library. Retrieved from https://books.google.co.id/books?hl=id\&lr=\&id= 3F5nDwAAQBAJ\&oi=fnd\&pg=PP1\&dq=Adiwarman+syariah+di+bidang+Ekonomi. \&ots=lyHCQRCYt2\&sig=InLSWAX1FNwayQmdgFTkMrGZOYY\&redir_esc=y\#v= onepage\&q=AdiwarmanshariainEconomics.\&f=false 
[35] Siregar, AE (1991). Flow of Economic Thought Politics. Yogyakarta: Tiara Discourse. 